\title{
Análise do contexto da Roda de Choro com base no conceito de ordem musical de John Blacking
}

\author{
Ivaldo Gadelha de Lara Filho (UNB, Brasilia, DF) \\ ivaldogadelha@gmail.com \\ Gabriela Tunes da Silva (Câmara Legislativa do Distrito Federal, DF)
gabitunes@gmail.com
}

Ricardo Dourado Freire (UNB, Brasília, DF)

freireri@unb.br

\begin{abstract}
Resumo: A Roda de Choro oferece um rico ambiente para análise tanto do contexto musical da performance quanto do contexto social que nutre as relações musicais. No presente artigo, essa especificidade é analisada a partir do conceito de ordem musical estabelecido por John Blacking (1995). A coleta de dados da pesquisa foi realizada a partir de observações etnográficas e entrevistas com os músicos participantes do universo do Choro. A análise dos discursos e dos registros pode auxiliar na identificação dos elementos que compõem esta ordem musical dentro do Choro conforme a proposta do etnomusicólogo. 0 contexto ilustrado na discussão é uma Roda de Choro regularmente realizada em um bar de Brasília com a presença de músicos vindos de vários lugares do Brasil. Os relatos dos chorões apontam para a importância da existência de Rodas para manutenção e recriação da tradição musical do Choro. Foi possível compreender que, para esse gênero musical, uma série de fatores extra-musicais interfere de modo significativo nas performances dos músicos.

Palavras-Chave: choro; roda de choro; etnomusicologia; John Blacking.
\end{abstract}

\section{The Roda de Choro musical and social analysis based on John Blacking's concept of musical order}

Abstract: The Roda de Choro offers a rich environment in order to analyze the musical context of performance and the social context which nourishes the musical relations. This article aims at analyzing the relationship of both musical and social contexts according to the concept of musical order established by John Blacking (1995), who argues that "music cannot exist without the perception of order that organizes sound". Empirical data was carried through interviews and based on ethnographic field work realized during eighteen months in a live music restaurant in Brasilia. Through discourse analysis and registers analysis it was possible to identify elements which form musical order inside the Choro according to the musician's proposal. Analyses unveil the role of Rodas de Choro as social contexts for maintaining and to recreating choro musical tradition. As a musical gender, Choro involves a whole set of extra-musical factors that impacts musicians' performance.

Key-Words: Brazilian choro; roda de choro; ethnomusicology; John Blacking.

\section{1- Introdução}

No Choro, assim como em qualquer outro tipo de manifestação de música popular, o estudo da prática da interpretação musical (performance) torna-se um desafio para trabalhos de natureza acadêmica, pois inclui uma série de elementos subjetivos e complexos para serem descritos com precisão. Todavia, a interpretação musical é um dos aspectos mais importantes no gênero, sendo uma de suas marcas registradas. Em sua trajetória histórica, os compositores e suas obras exerceram um papel impor- tante, mas foi na arte da interpretação que essa música alcançou seu elemento identificador mais contundente. Músicos e ouvintes do Choro, ao observarem performances de chorões, são capazes de emitir julgamentos sobre ela. Mesmo divergindo muitas vezes sobre alguns aspectos, esses julgadores, em sua grande maioria, convergem quanto à atuação. Isso permite inferir que há uma ordem que organiza o Choro como sistema musical, e que tal ordem é reconhecida pelos chorões, músicos ou audiência. 
Gerard BÉHAGUE (1984), em estudos sobre performance musical, afirma que a etnografia da perfomance deve trazer à luz os modos como os elementos não-musicais, numa determinada ocasião influenciam os musicais. 0 referencial fornecido por BÉHAGUE (1984) aponta para a impossibilidade de se compreender um sistema musical desvinculado do contexto geral em que se insere. 0 conhecimento do contexto permite que as análises dos parâmetros musicais sejam mais facilmente realizadas e compreendidas, porque abordadas a partir do conhecimento do ambiente musical do Choro, composto não somente pela música como também por inúmeros outros elementos.

De acordo com diversos autores (dentre eles, podemos destacar BLACKING, 1973; e QURESHI, 1987), no estudo de sistemas musicais não totalmente ancorados no registro escrito convencional, é importante levar em consideração os conceitos, as teorias, e os conhecimentos musicais dos músicos que compõem tais sistemas. Isso quer dizer que o uso das ferramentas da teoria musical ocidental pode não ser adequado para o entendimento e para as análises desses sistemas musicais. Para os musicólogos, os conceitos cunhados pelos próprios músicos são aqueles que melhor representam seus sistemas musicais. Portanto, é tarefa do pesquisador identificar esses conceitos e conhecimentos, tentando manter fidelidade ao modo como são expressos dentro de seu sistema cultural originário. Mesmo que um sistema musical não se baseie em uma teoria musical, existem conhecimentos subjacentes acerca da ordem sonora. Nas palavras de John BLACKING (1973):

\footnotetext{
Quando afirmo que a música não pode existir sem a percepção da ordem que orienta o som, não estou argumentando que algum tipo de teoria musical deva preceder a composição e a performance musical: isso deve ser obviamente falso para a maior parte das grandes composições clássicas e para o trabalho dos chamados músicos 'folk'. Estou sugerindo que a percepção da ordem musical, não importa se inata ou aprendida ou ambas, deve estar na mente antes de emergir como música. (BLACKING, 1973, p.11)
}

Tomando como válida a assertiva de BLACKING (1973), supõe-se possivel identificar uma ordem sonora subjacente às performances do Choro; além de constatar que os chorões têm consciência dessa ordem. No contexto do Choro, os entendimentos pessoais e individuais existentes sobre a ordem sonora do Choro irão contribuir inclusive para a consolidação dos estilos individuais de instrumentistas. É possivel também perceber elementos cuja presença é crucial para as performances do Choro.

Desse modo, se a pesquisa investigar a percepção da ordem musical dos músicos integrantes desse universo poderá identificar elementos dessa ordem. Uma forma de se ter acesso a esses conhecimentos é permitir aos músicos a verbalização de seus conceitos e de suas percepções. BLACKING (1995) postula que o julgamento da performance no âmbito de uma tradição musical, ou seja, a capacidade de dizer o que é bom ou ruim, certo ou errado em um determinado sistema musical, baseia-se em princípios adquiridos na vida social em processos que nem sempre estão diretamente ligados à prática musical. Com isso, BLACKING (1995) infere que é possivel aprender música simplesmente sendo parte de uma coletividade humana, organizada por uma ordem que se expressa, entre outros, na música dessa coletividade.

Contrariamente KERMAN (1987) afirma que toda interpretação é individual, pois o músico deve imprimir à obra sua personalidade, seu sentimento e sua intuição. A interpretação é o modo como a individualidade do músico influi na individualidade da obra. Ele ressalta que os músicos inseridos em uma tradição viva não precisam escrever ou falar sobre a música que executam para manterem a tradição. Importante para isso é a constante produção, interpretação e reinterpretação das músicas. Na visão do autor, uma tradição musical não mantém sua "vida" ou continuidade por meio de livros e da sabedoria livresca. Ela é transmitida em lições privadas, não tanto por palavras, mas também pela linguagem corporal; não tanto pelo preceito como também pelo exemplo. Afirma ainda que isso não significa que os músicos não reflitam ou pensem sobre sua prática musical; apenas não têm o hábito de articularem isso em palavras ou de registrarem em pentagramas. No fundo, isso não é necessário, pois a prática musical já é suficiente. No Choro, ao contrário do que acontece na música erudita, não é comum o registro detalhado por escrito das interpretações. As gravações, contudo, deixam registradas interpretações que acabam se tornando célebres. Desta forma fica eternizada a criatividade de grandes intérpretes que será exemplo para vários instrumentistas. Mas, de algum modo, ao seguir os exemplos e se deixar influenciar, o intérprete deve subverter a imitação do modelo, e criar seu estilo interpretativo próprio. John BLACKING (1995) afirma que, se a música é o som organizado pelos homens, ela deve conter reflexos da organização social em que seus produtores estejam inseridos. Se considerarmos que a interpretação é o modo como um indivíduo expressa sua pessoalidade em um sistema musical, pode-se inferir que a interpretação deve conter, também, reflexos do modo como o intérprete compreende sua realidade e seu sistema social. A interpretação, portanto, traz elementos que estão além do seu entendimento da ordem sonora de um sistema musical; levando em conta os conceitos de BLACKING (1995) e KERMAN (1987), é a verdadeira expressão de uma pessoa. Diante disso, percebe-se que o estudo da performance e da interpretação irá acessar aspectos da ordem sonora de um sistema musical - reflexo da ordem social que organiza uma coletividade; mas irá, também, acessar os modos como cada intérprete compreende tal ordem sonora, e como ele se vê e se insere na ordem social da qual faz parte.

A partir de uma análise categorizada do discurso dos chorões de Brasília, foram identificados diversos elementos musicais utilizados na avaliação da performance na roda de choro. Dentre eles podem ser destacados: sonoridade, formação instrumental, repertório, virtuosismo, expressi- 
vidade e emoção, capacidade de decorar (não tocar lendo), erros (o modo como o músico lida com erros), ritmo (citado como balanço, ginga, malandragem - elementos próprios do Choro e de outras manifestações da cultura brasileira), variações e improvisação.

\section{2- A Roda de Choro}

A Roda de Choro é um dos contextos de performance mais característicos do Choro, que pode ser considerada sua matriz. Marcada pela informalidade, nela não estão definidos, a priori, aspectos como: quem irá tocar, quando, como, com quem ou quanto irá tocar; trata-se de um encontro entre músicos, com a presença de uma audiência; há um limite fluido entre músicos e audiência, pois todos são audiência. Em geral, os músicos intercalam-se na performance, e cada músico é audiência dos outros músicos no momento da execução do Choro. Podemos caracterizar a Roda como um conjunto de círculos concêntricos, sendo que, no primeiro círculo, estão os músicos (geralmente em volta de uma mesa); no segundo círculo, os interessados pela música (conhecedores desse universo musical e participantes do ambiente de relações pessoais dos músicos); nos círculos subsequentes ficam os frequentadores do ambiente musical - algumas vezes interessados apenas na interação social. Muitas vezes, essa classificação circular não é observada, e as pessoas se misturam constantemente.

A Roda é um encontro de pessoas, e vincula-se ao lazer, tendo, quase sempre, ares de festejo. Dois aspectos musicais reforçam seu caráter informal: não há ensaio e ela é aberta. Sendo um encontro, para que aconteça a roda, não há sentido em realizar outros encontros preparatórios - os ensaios. A Roda é também aberta, pois, a princípio, todos podem tocar, desde que tenham certo domínio técnico do instrumento e sejam aceitos pelos músicos do momento. $A$ possibilidade de qualquer instrumentista presente na ocasião da Roda ter a liberdade de tocar reforça também seu caráter de encontro social. Ao contrário de muitas práticas musicais abordadas em estudos etnográficos, nas quais a música é apenas um dentre diversos elementos componentes de um ritual, a Roda de Choro tem a música por objetivo, pois ela é o elemento principal, o fator agregador de pessoas. Diante do exposto, pode-se dizer que a música origina o contexto, que, por sua vez, interfere na música. 0 ritual da Roda de Choro acontece porque existe a música; são indissolúveis contexto e música. São fatores importantes as pessoas presentes e as relações de troca que os músicos estabelecem entre si.

SCHUTZ (1977) defende que a música como modo de comunicação não se baseia na transmissão de conteúdos sonoros, mas na possibilidade de instaurar relações interpessoais. No caso da Roda, instrumentistas de diversos niveis tocam juntos, criando e recriando repertórios; nela a música exerce, dentre outras coisas, o papel de interlocução entre as pessoas. Assim, a Roda de Choro cria um ambiente de relações e, em contrapartida, apoia-se nele. Com efeito, o contexto interfere nos elementos musicais, que também alteram o contexto. Nesta visão, QURESHI (1987, p.65) afirma que o som musical varia com a variação no contexto da performance; no caso da Roda de Choro, o inverso também é válido.

Roberto M. MOURA (2004) realizou extenso trabalho sobre a Roda de Samba, que pode servir de referência para a análise das Rodas de Choro, pois ambos os gêneros estão ligados desde sua origem, e as características das Rodas guardam importantes semelhanças. Do mesmo modo, capoeira e candomblé são exemplos de manifestações de raiz negra que também reúnem características semelhantes às das Rodas de Samba e Choro. Para o caso da segunda, a análise de MOURA (2004) sobre as Rodas de Samba é particularmente pertinente, pois ambas são manifestações culturais em que a música desempenha o principal papel, diferentemente da capoeira e do candomblé, em que elementos de luta, dança e religião são tão importantes quanto a música. Como no caso do samba, a Roda antecede o Choro e é sua matriz física; não foi o Choro que criou a Roda, mas o contrário. Ao longo de sua existência, o gênero incorporou instrumentos, alterou formas e harmonias, criou novos estilos e sofreu uma série de outras modificações. Mas a Roda permaneceu. Mais do que apenas um dentre vários contextos em que o Choro ocorre, a Roda é elemento fundamental na geração, preservação e divulgação desse gênero musical (MOURA, 2004, p.29). Assim, as características de performance e contexto presentes na Roda são, sem dúvida, cruciais para o entendimento da natureza do Choro.

No livro No princípio Era a Roda: um estudo sobre samba, partido alto e outros pagodes (MOURA, 2004), o autor tenta refazer a trajetória histórica do Samba a partir das Rodas de Samba no Rio de Janeiro desde o final do século XIX aos dias atuais. Ele afirma que, embora seja um ritual, cada Roda é única e não pode ser repetida. Seu código se funda na família, na amizade, na lealdade, na pessoa e no compadrio (MOURA, 2004, p.28). Como em qualquer ritual, a Roda preserva e atualiza o que está em sua origem. Ela é antes de tudo um evento festivo de caráter plural, familiar; um espaço mítico resultante da dialética entre 0 cotidiano e a utopia; ela instaura a ilusão da eternidade (MOURA 2004 p.23). É um espaço em que o que é íntimo se confunde e se mistura com o que é coletivo. Compreende música, comida, bebida, alegria e um conjunto de relações, e funciona como suporte de processos de interação e comunicação entre as pessoas. Não são os sambistas que formam a Roda, mas o contrário. Isso se deve em grande parte ao ambiente doméstico, familiar, íntimo, caseiro em que ela se dá (MOURA, 2004, p.39).

Como referencial para suas análises sobre a Roda de Samba e o inexorável processo de profissionalização dos sambistas e suas inserções no mercado fonográfico, MOURA (2004) adota as categorias sociológicas "casa" e "rua", criadas pelo antropólogo Roberto DaMatta. Esses termos designam mais que simples espaços geográficos ou coisas físicas comensuráveis; designam: 
(...) acima de tudo entidades morais, esferas de ação social, províncias éticas, dotadas de positividade, domínios culturais institucionalizados e, por causa disso, capazes de despertar emoções, reações, leis, orações, músicas e imagens esteticamente emolduradas e inspiradas." (DAMATTA 1997, apud MOURA, 2004, p.41).

0 autor afirma ainda que, do mesmo modo que é possível fazer uma leitura do Brasil do ponto de vista da casa em contraponto à rua, é possivel ler o Samba através da Roda em contraponto à Escola de Samba nascida como casa e transformada em rua. Assim, na casa/roda as leituras ressaltam a pessoa; a casa propicia a formação da Roda como manifestação espontânea e festiva. Já na escola/rua há uma ênfase no indivíduo, os discursos são mais rígidos e instauradores de novos processos sociais (MOURA, 2004). Visto desta maneira, nota-se que a Roda não é passível de se transformar em produto, ao contrário do samba. Ela é descrita antes como uma expressão comunitária (mais utópica e amadora); seu aspecto mais comercial caminha na direção da escola de samba (mais pragmática e mercantil).

A música que soa na Roda é, coerentemente com a abordagem de SCHUTZ (1977), produzida verdadeiramente em conjunto. Para MOURA (2004, p.37), o ambiente musical da Roda não separa música e vida, lazer e produção, sendo mais do que apenas um evento musical, mas uma opção política, um modo de vida, que inclui desde círculos de amizade até vestimentas, comidas, bebidas, gestos, discursos e expressões. Muitos músicos realizam essa entrega total à música, de modo que o Samba (ou o Choro) se torna sua principal marca de identificação.

A Roda apresenta muitas características das coletividades humanas, sendo a hierarquia uma delas. Todavia, os critérios delimitadores dessa hierarquia dentro de uma Roda de Choro ou de Samba são diversos daqueles passíveis de demarcarem hierarquias em outros ambientes. De modo simplificado, nada do que o sujeito é ou tem ou faz fora da Roda importa para aqueles que estão dentro dela:

\footnotetext{
Pode (...) certo artista ser um indiscutível sucesso de vendas ou execução. Pode ser um ídolo do rádio, do cinema ou da televisão. Pode bater recordes. Nada disso Ihe assegura qualquer respeitabilidade ou diferenciação dentro da Roda. Seu lugar será sempre determinado pelo que for capaz de fazer ali - e ali não é lugar de mentira. (MOURA, 2004: 44).
}

Sem dúvida, no caso do Choro, a performance do músico é o principal elemento que irá garantir sua respeitabilidade. Evidentemente, outros fatores podem intervir, tais como: antiguidade na Roda, reconhecimento, histórico pessoal, ou até o carisma. Mas a performance, a capacidade de tocar bem, a demonstração de talento e criatividade são cruciais para um músico na Roda.

Muitas vezes, outras manifestações da cultura popular brasileira que incluem a música têm na Roda sua matriz. CÂMARA CASCUDO (2002, P. 592) afirma que as três etnias que deram origem ao povo brasileiro (negros, portugueses e índios) possuíam suas danças de roda. Segundo ele, a Roda não é nenhuma novidade, pois a primeira dança humana, expressão religiosa instintiva, a oração inicial pelo ritmo, deve ter sido em roda, dançada ao redor de um ídolo. Com efeito, encontramos inúmeras manifestações da cultura popular cuja organização se dá em forma de roda. Mas teriam essas outras rodas características semeIhantes àquelas observadas nas Rodas de Samba, descritas por Roberto MOURA (2004), e nas de Choro? Tomemos a capoeira como exemplo. VIEIRA e ASSUNÇÃO (1998) afirmam que o jogo da capoeira, até o início dos anos 30, integrava-se às práticas cotidianas das classes populares de modo semelhante aos jogos de futebol informais (peladas), pois consistia em encontros entre pessoas cujo aprendizado se dava no exercício prático do jogo. Havia pontos tradicionais de reunião dos capoeiristas, principalmente nos domingos à tarde, tais como bares, praças, mercados e feiras. Não havia indumentária especial, mas os capoeiras mais experientes costumavam trajar ternos de linho branco, pois sua destreza se demonstrava ao sair da brincadeira com a roupa perfeitamente limpa. Os autores enfatizam que, embora o universo da capoeira envolvesse violência e frequentes embates entre grupos rivais e com a polícia, seu caráter essencial era lúdico. A roda de capoeira era vista como folguedo, encontro. Afirmam também que a capoeira é marca identitária de seus praticantes, e apontam a malandragem, a mandinga, como um dos elementos mais valorizados na performance do capoeirista. 0 duelo jocoso é a marca do jogo da capoeira; embora seja complexo a ponto de ser um jogo em que quase nunca é possivel apontar um vencedor, há sempre o objetivo de derrubar o outro, por meio de golpes desequilibrantes. Todavia, nem sempre isso ocorre, e o jogo não perde seu valor por isso. No mesmo sentido, REIS (1997) afirma que o ethos da capoeira é marcado pela ambiguidade lúdicocombativa, que prefere o confronto indireto, disfarçado, ao embate aberto. A malandragem é a maliciosa capacidade de dissimular, de esconder as verdadeiras intenções do jogador. A ginga, base móvel da capoeira, é um tipo de movimentação que permite ao capoeira utilizar maneirismos e mandingas que confundem o outro jogador. Desse modo, ele torna seu jogo completamente imprevisível, nunca sujeito a ser conhecido por antecipação, mesmo nas últimas frações de segundo que antecedem sua movimentação. 0 jogo da capoeira é sempre improvisado.

Dentro da variedade de fontes que tratam da história do gênero, destaca-se a obra Choro: A Social History of a Brazilian Popular Music (LIVINGSTON-ISENHOUR e GAR$C I A$, 2005). Em um capitulo inteiro dedicado à Roda, os autores destacam os aspectos musicais (a formação instrumental, o repertório, a improvisação, o aprendizado, a interpretação, e outros) e também os sociais (os códigos de conduta, o papel das amizades, a hierarquia, a interação, a informalidade, a devoção, a paixão etc). Torna-se importante discutir os modos como os autores entendem a autenticidade de uma Roda. Para eles, existem dois tipos: a Roda pura, considerada também como original, e a Roda de Apresentação. Na primeira, os músicos não são remunerados, qualquer um pode tocar e não existe ne- 
nhum aparato tecnológico para a amplificação dos instrumentos. Na outra, os músicos são assalariados, contam com o apoio de uma infra-estrutura de sonorização e a participação de outros músicos dependerá do grau de intimidade tida com os outros membros da Roda. Os autores afirmam que esse segundo modelo descaracteriza a Roda pura, pois o fato de os chorões contarem com o apoio de recursos tecnológicos instaura outros modos de relação entre músicos e audiência. Ademais, o profissionalismo exigido reduz os espaços de expressão da pessoalidade, e cria um distanciamento entre músicos e músicos e entre músicos e audiência. A Roda só é autêntica se houver a máxima interação entre os músicos e a audiência. (LIVINGSTON-ISENHOUR e GARCIA 2005, p.54).

Nesse ponto, algumas considerações são pertinentes. 0 contraponto, por excelência, da Roda de Choro, é a apresentação, geralmente realizada em teatros e casas de espetáculos, e cujas características são opostas àquelas observadas na Roda. Em termos gerais, o repertório é preestabelecido e a apresentação é precedida de ensaios. Por isso, são feitos arranjos para a maioria das músicas; em muitos casos, a estrutura e a forma do Choro são alteradas, justamente por existirem ensaios prévios. A apresentação é marcada pela formalidade e pelo profissionalismo. 0 público assume a postura de espectador, ou seja, consumidor passivo do espetáculo apresentado. Para os músicos, não faz diferença quem os está assistindo, pois a distância que os separa da audiência é grande, tanto no âmbito físico quanto no psicossocial. Ocorre que, muitas vezes, as Rodas de Choro acabam por incorporar alguns elementos da apresentação, vez que são capazes de atrair público. Então, é comum que produtores de eventos, donos de estabelecimentos, entre outros, promovam Rodas de Choro periódicas, a fim de verem crescer seus negócios. Todavia, para que aconteçam, para que atraiam o público, é preciso garantir, primeiramente, que exista um mínimo de músicos presentes, capazes de executar os Choros. Assim, nesses casos, um conjunto regional é contratado para garantir a música; todavia, não Ihes são exigidos ensaios, repertórios definidos, e a participação de outros músicos é aberta. Em segundo lugar, é preciso amplificar o volume do som, para que a audiência escute a música; existem, portanto, Rodas de Choro com som amplificado. Por fim, em alguns casos, quando alguma Roda de Choro começa a se destacar pela qualidade musical, é comum que o dono do estabelecimento e/ou os próprios músicos realizem filtragens daqueles que poderão participar, vetando a entrada de músicos muito iniciantes e inexperientes, que podem comprometer o nível da performance da Roda como um todo. LIVINGSTON-ISENHOUR e GARCIA (2005) entendem que quando há som amplificado, pagamento de músicos fixos e filtragem de participantes, o evento, embora denominado Roda de Choro, perde sua autenticidade como tal. Defendem esses autores a ideia de que somente é autêntica aquela Roda de Choro considerada pura, ou seja, que acontece sem nenhum outro objetivo a não ser o encontro de músicos, e sem interferências de elementos externos a ela própria e à música.

Propomos, aqui, um outro modo de entendimento da Roda de Choro. Para tanto, será utilizada a abordagem metodológica proposta por Max WEBER (1993), que se baseia na construção de tipos-ideais. Um tipo-ideal é uma abstração que contém um conjunto de elementos que, embora encontrados na realidade, não necessariamente o são do mesmo modo como estão na representação típica-ideal. 0 tipo-ideal não é uma representação nem uma descrição, mas sim um conceito que funciona como ferramenta de análise, cuja finalidade é auxiliar a compreensão da realidade. Nas palavras de Weber:

\begin{abstract}
Obtém-se um tipo ideal mediante a acentuação unilateral de um ou vários pontos de vista, e mediante o encadeamento de grande quantidade de fenômenos isoladamente dados, difusos e discretos, que se podem dar em maior ou menor número ou mesmo faltar por completo, e que se ordenam segundo os pontos de vista unilateralmente acentuados, a fim de se formar um quadro homogêneo de pensamento. Torna-se impossível encontrar empiricamente na realidade esse quadro, na sua pureza conceitual, pois se trata de uma utopia. A atividade historiográfica defronta-se com a tarefa de determinar, em cada caso particular, a proximidade ou afastamento entre a realidade e o quadro ideal (...) Ora, desde que cuidadosamente aplicado, esse conceito cumpre as funções específicas que dele se esperam, em benefício da investigação e da representação. (WEBER, 1993, p.137).
\end{abstract}

A descrição da Roda, conforme proposta por Roberto MOURA (2004), pode ser entendida como uma construção típico-ideal de um contexto em que o Choro ocorre; a apresentação formal teria, então, características diametralmente opostas, sendo, também, um tipo-ideal. 0 que observamos no plano real, contudo, são situações híbridas desses dois contextos, que contêm elementos de um e de outro, em maior ou menor grau (Ex.1).

A polaridade roda/apresentação é presente quase sempre nos discursos que tratam do Choro. Músicos, ouvintes, apreciadores, produtores, donos de comércio, intelectuais, acadêmicos e artistas, enfim, todos que tem alguma relação com o gênero, costumam possuir também opinião formada acerca dessa polaridade. Alguns discursos valorizam a apresentação em relação à Roda, apoiados na ideia de que a formalização e a profissionalização indicam que o gênero está sendo valorizado. De outra mão, há aqueles que defendem a autenticidade do choro somente nas Rodas, onde existe informalidade e pessoalidade. Em defesa da Roda, levanta-se o argumento da tradição: é comum associar a origem do Choro ao ambiente das Rodas. A partir daí, surge a ideia de que está havendo uma espécie de degeneração do gênero, cuja origem é a profissionalização dos músicos e a associação do Choro com o comércio do entretenimento. Ao mesmo tempo, alimentase o desejo nostálgico de volta ao tempo do "verdadeiro" Choro, aquele tocado em Rodas nos quintais e botecos. Esse argumento contribui, também, para a criação de uma visão romântica da Roda de Choro, como sendo um local que as pessoas frequentam por motivos nobres $\mathrm{e}$ 


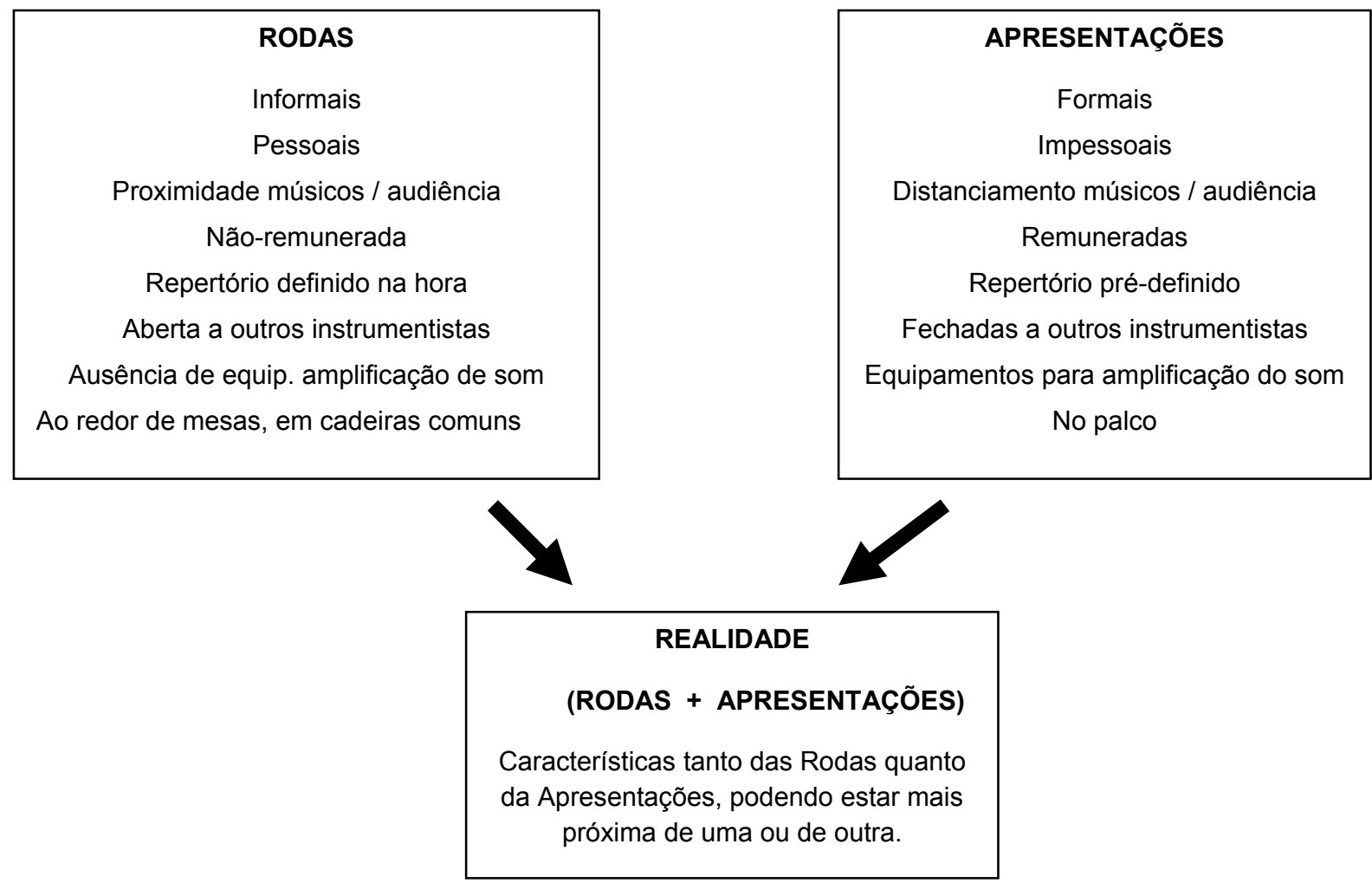

Ex.1: Resumo esquemático de dois contextos de performance típicos do Choro.

altruistas, movidas apenas pela beleza da música e dos encontros entre pessoas, onde reinam a mais perfeita harmonia e as mais sólidas amizades, e onde não há lugar para mesquinharias e outros sentimentos e atitudes vis e baixos. Essa visão romântica é, obviamente, equivocada e distante da realidade.

É interessante notar que CAZES (2005), faz referência ao antagonismo Roda/Apresentação já no título - Choro: do quintal ao municipal. 0 título transmite a ideia de que 0 Choro, em sua trajetória histórica, partiu de um ambiente amador/informal (o quintal, local onde as Rodas mais simples e espontâneas acontecem) para um formal/profissional (o Teatro Municipal, ambiente glamoroso, onde somente grandes artistas se apresentam), obtendo merecido reconhecimento. Todavia, o prefácio do livro, escrito por Hermano Vianna, traz considerações sobre o título e sobre o antagonismo roda/apresentação:

Do quintal ao Municipal sim, mas também de volta ao quintal novamente, e assim sem parar, num movimento de ida e vinda (não se sabe ao certo qual é o território de origem) que confunde muitas noções preestabelecidas, como a de alta e baixa cultura, ou como erudito e popular. Em cinquenta anos, a banda de Anacleto de Medeiros já apresentara uma seleção de temas de II Guarany, Villa-Lobos já frequentava as rodas de Choro na casa do pai de Pixinguinha; e o pioneiro do violão chorista, Sátiro Bilhar, tocara tam- bém música clássica. Então, quem veio primeiro: 0 quintal ou o Municipal? Puxo a brasa para a minha sardinha, e para o que penso ser o traço mais interessante de tudo aquilo de vital que aconteceu e acontece na cultura carioca e brasileira: nem o quintal nem o Municipal. 0 melhor acontece "entre", na possibilidade de ultrapassar as fronteiras rígidas que separam os vários mundos culturais, na tradução entre as várias linguagens musicais, na genial atuação de mediadores (entre-mundos, entre-linguagens) como Pixinguinha, Radamés Gnatalli(...). (VIANNA, Hermano, In: CAZES, 2005, p.8-9)

Ao longo da história do Choro, conforme indicou Hermano Vianna, a polaridade roda/apresentação esteve sempre presente. Também é fato que, na maioria das vezes, os músicos participantes das apresentações são os mesmos frequentadores das rodas e conhecedores dos dois contextos, das diferenças que guardam entre si e dos códigos de conduta em cada um deles.

LIVINGSTON-ISENHOUR e GARCIA (2005, p. 42) também fazem referências à tensão roda/apresentação. Enfatizam a importância da Roda como matriz do Choro, e a descrevem também em contraposição com o contexto da apresentação. Todavia, não refletem sobre a existência de situações híbridas, que misturam elementos dos dois contextos. Segundo eles, para os chorões, o Choro "verdadeiro" somente se ouve na Roda, e a qualidade 
da Roda é julgada não somente pelo nível dos músicos, mas pelo grau de participação: uma roda em que apenas poucas pessoas tocam (...) não é considerada "verdadeira". No capítulo que dedicam às Rodas de Choro, os autores fazem referência a várias delas. Uma ficcional, imaginada a partir dos relatos de Alexandre PINTO (1978) sobre o ambiente do Choro no início do século $X X$, com o objetivo de descrever uma Roda antiga. Duas outras tiveram participação dos autores do livro, e cuja realização se deu exatamente para que eles pudessem participar; a primeira foi considerada uma roda de amadores, por ser formada por músicos de nível técnico intermediário; a segunda foi definida como roda de profissionais, porque dela participaram músicos consagrados, como Joel Nascimento, Maurício Carrilho e Luciana Rabello. Há também a descrição de uma Roda de Choro em Brasília, realizada na residência do Dr. Assis, chorão conhecido na cidade por Six, pelo fato de possuir seis dedos nas mãos. Essa Roda durou cerca de três dias, pois era costume do Six realizar eventos intermináveis, e contou com a participação de grandes nomes da música instrumental brasileira, como Arthur Moreira Lima e Carlos Poyares. Pela longa duração da festa, a roda teve momentos diferentes, alguns mais formais, outros extremamente informais, e obviamente muitos choros foram repetidos.

Por fim, os autores descrevem a Roda do "Choro na Feira", que aconteceu em maio de 2003. Eles diferenciam essa Roda das demais descritas por ser uma Roda de Apresentação. Definem esse termo - Roda de Apresentação - como sendo um contexto em que, embora aparente ser uma roda espontânea, na realidade consiste em um grupo de músicos, relativamente flexivel, que se encontra todo sábado em Laranjeiras (LIVINGSTON-ISENHOUR e GARCIA, 2005, p.54). São, portanto, Rodas de Choro com características de apresentação. Os autores chegam a afirmar que, nesses casos, os músicos são pagos para agirem como se estivessem em um "evento espontâneo". Desta maneira, nas rodas contratadas como eles as denominam, haveria uma grande dose de cinismo, pois que pretendem literalmente enganar o público. Nelas, a aparente espontaneidade confunde a audiência: o fato de não haver palco, e dos músicos tocarem fisicamente próximos da audiência, faz com que o público pense que se trata de uma Roda. Quanto à participação de outros músicos, afirmam que ela é limitada a instrumentos percussivos auxiliares (qualquer um menos pandeiro e surdo). Todavia, descrevem uma situação em que um violonista desconhecido dos músicos solicitou a participação na Roda e foi atendido; os solicitados, contudo, consideraram sua performance ruim e, embora o tenham tratado cordialmente, demonstraram, com sutis expressões faciais, que não estavam apreciando. Apesar disso, deixaram-no tocar por um tempo. Para LIVINGSTON-ISENHOUR e GARCIA (2005), a participação do violonista foi possivel porque o violão tem volume baixo, e não compromete tanto a sonoridade geral da Roda; caso fosse um trombonista, por exemplo, certamente teria sua participação negada. Os autores entendem, assim, que quando há músicos fixos e pagos, a Roda tem falsa espontaneidade, e não deve ser considerada como tal. Além do pagamento, apontam a amplificação do som como outro elemento que descaracteriza a Roda de Choro: a questão da amplificação não esteve presente em nenhuma das rodas que participamos, principalmente porque os requisitos estéticos de uma roda são substancialmente diferentes daqueles de um concerto (LIVINGSTON-ISENHOUR e GARCIA, 2005, p.56).

Com base nessas observações, LIVINGSTON-ISENHOUR e GARCIA (2005) concluem que:

(...) houve uma mudança crucial nos últimos vinte anos na prática
e na percepção do choro; ele deixou de ser uma tradição essen-
cialmente participativa, baseada na roda, para ser uma tradição de
apresentações e gravações, representada pelas gerações mais jo-
vens. 0 renascimento [do choro no final do século XX] introduziu o
choro a um novo setor social - a juventude universitária de classe-
média e classe-média-alta. Nesse processo, o choro foi adaptado às
preferências e à sensibilidade musical dos novos chorões. Além de
serem capazes de ler e compor músicas, esses músicos geralmente
têm uma orientação cosmopolita que os distingue das gerações an-
teriores de chorões (LIVINGSTON-ISENHOUR e GARCIA, 2005, p.57)

Desse modo, fica claro que, para LIVINGSTON-ISENHOUR e GARCIA (2005), não existe meio-termo entre os contextos da Roda e da Apresentação, pois cada evento deve ser enquadrado em uma ou outra categoria. Quando elementos típicos da Roda estão ausentes, eles a consideram falsa, mesmo que seja denominada como tal. Além disso, conforme indica a citação acima, esses autores relacionam a redução das Rodas de Choro autênticas ao fenômeno contemporâneo do renascimento do Choro, cujos protagonistas são, principalmente, jovens de classe-média bem formados e informados. Esse setor da sociedade dá alto valor às apresentações e gravações de discos; desse modo, realizam Rodas de Choro voltadas para um público com grupos fixos, pagos para tocar e, muitas vezes, com som amplificado. Para LIVINGSTON-ISENHOUR e GARCIA (2005), essas não são Rodas verdadeiras. Todavia, na história do Choro, sempre esteve presente a polaridade roda/apresentação e seus hibridismos. Os chorões eram familiares aos ambientes informais tanto quanto aos mais formais possiveis, pois estavam acostumados a se apresentar para a corte e a alta sociedade. Também sempre foram comuns Rodas de Choro em estabelecimentos comerciais, visando a aumentar o movimento, e com retornos financeiros aos músicos. Conforme afirma Hermano Vianna, o Choro não acontece nem no quintal nem no Municipal, mas no espaço entre esses dois mundos culturais aparentemente apartados. Com base nisso, podemos afirmar que as Rodas do Choro na Feira não são, como afirmam LIVINGSTON-ISENHOUR e GARCIA (2005), falsas, mas possuem caracteristicas diferentes daquelas exclusivamente domésticas, sem, que por isso, sejam menos autênticas. De fato, não é possivel sequer julgar em qual contexto o Choro é "mais autêntico", se na Roda ou na Apresentação, uma vez que ambos estiveram presentes ao longo da história do gênero, fazem parte dele e são igualmente importantes para o seu desenvolvimento. Podemos, ainda, afirmar que a polaridade roda/apre- 
sentação reflete a tensão casa/rua, descrita por Roberto DAMATTA (1997) e utilizada por Roberto MOURA (2004) para explicar os contextos da Roda e da escola de samba. A roda equivale à casa, em que imperam a informalidade e a pessoalidade, e a rua equivale à apresentação, marcada pela impessoalidade e pelo profissionalismo. A partir desse aforismo, podemos dizer que o Choro ocorre, na maior parte das vezes, não na casa, nem na rua, mas na calçada, ou no alpendre, com o portão aberto para quem quiser entrar.

\section{3- Estudo de caso: análise de uma Roda de Choro em Brasília - DF}

Em Brasília, Rodas de Choro ocorrem nos quintais das belas casas dos Lagos Norte e Sul, nos apertados bares e restaurantes do Plano Piloto, nas salas dos generosos apartamentos da Asa Sul e Asa Norte ou em bares e restaurantes que abrem espaço para música ao vivo. Este artigo realizou um estudo etnográfico sobre as rodas de choro realizadas em uma Lanchonete sempre às sextasfeiras. Essas rodas merecem destaque pela presença de muitos e importante músicos da cidade, bem como pela regularidade com que ocorrem desde 2004.

A Lanchonete Tartaruga Lanches localiza-se no Plano Piloto de Brasília, área nobre, de classe-média e classemédia alta. A Roda da Tartaruga reflete as características do ambiente do Choro na cidade. Entre os músicos que frequentam a Roda, existe enorme diversidade de origens familiares (cariocas, nordestinos, mineiros, sulistas, goianos, paulistas), de classes econômicas e níveis de renda, de escolaridade e de formação musical. Há, também, predominância de jovens, entre 20 e 35 anos, embora a Roda seja constantemente visitada pelos chorões das velhas gerações. Dentre os ouvintes, predominam funcionários públicos, profissionais liberais e estudantes universitários, ocupações típicas da classe média. A composição da audiência decorre, sem dúvida, do fato de a lanchonete estar localizada em bairro nobre da cidade.

As Rodas da Tartaruga Lanches tiveram início em meados de 2006, assim que a lanchonete/bar, de propriedade de dois irmãos músicos e chorões, foi inaugurada no final da Asa Norte. Antes disso, funcionava em um pequeno trailler de Kombi, sem motor, estacionado no Campus da Universidade de Brasília, ao lado do Departamento de Música. Seus donos, Paulo e Rogério, desde a adolescência estavam envolvidos com música, e participaram de várias bandas da cena da cidade. Na Tartaruga, iniciaram contato com os estudantes de música, dentre os quais alguns jovens chorões. Assim, Rogério começou a estudar pandeiro e Paulão, bandolim. A partir de 2004, a Tartaruga Lanches passou a promover modestos encontros, às sextas-feiras a partir das $18 \mathrm{~h} 00$, entre estudantes de música que gostavam de tocar Choro. As reuniões eram pequenas, com menos de 30 pessoas. Em 2006, os irmãos transferiram a Tartaruga Lanches para um local maior, no final da Asa Norte, e continuaram a promover encontros musicais nas sextas-feiras à tarde.
As primeiras rodas não tinham um grupo fixo de instrumentistas. Os músicos se sentavam ao redor de uma mesa comum, em que os irmãos ofereciam alguns petiscos, uma garrafa de cachaça e cerveja. A audiência era reduzida, e composta por amigos e por músicos. Numa das primeiras Rodas, realizada em 20/10/2006, foi registrada a presença de 12 instrumentistas, do total de 30 pessoas que estavam no local. Ao longo de um ano, as Rodas aconteceram sem um regional fixo, porém com a presença constante de 10 a 15 instrumentistas.

A audiência, contudo, foi aumentando a cada semana e, atualmente, varia entre 100 e 200 pessoas. 0 som de todos os instrumentos é, por necessidade, amplificado, sendo que há microfones para instrumentos de sopro e cabos para os de corda. Hoje existe, também, um grupo fixo de músicos contratados, que tem o compromisso da presença em todas as Rodas, e cuja função é garantir que a música aconteça, independentemente da presença ou da ausência de outros instrumentistas.

Muito embora sempre exista uma grande quantidade de músicos na Roda, que por vezes chega a 20 ou 30, certas regras definem a composição do grupo que toca em cada momento. Sempre há somente um pandeiro, um violão de sete cordas e um cavaquinho fazendo o centro (harmonia e ritmo); outro violão pode auxiliar na harmonia e outro cavaquinho pode entrar para fazer o solo. Quanto aos solistas, vários podem tocar a mesma música, porém sempre um de cada vez, dividindo entre si as partes da música. As observações das Rodas documentaram que já se apresentaram como solistas: clarineta, flauta, cavaco, bandolim, trombone, saxofone, violino, gaita, trompa, acordeom e viola caipira.

0 objetivo da Roda de Choro é a possibilidade de os músicos tocarem uns com os outros, sem ensaio ou pré-determinações de repertórios e arranjos. Por isso, a Roda de Choro não dá espaço para grupos e regionais de Choro realizarem apresentações ensaiadas. Em Junho de 2007, a Roda recebeu a visita de um regional, residente nos Estados Unidos, que iria se apresentar no Clube do Choro de Brasília. Eles chegaram, assumiram seus instrumentos, e começaram a tocar o repertório próprio do grupo. Um leve mal-estar pairou entre os demais músicos, que rapidamente foram substituindo os forasteiros, para que se misturassem com os instrumentistas da Roda e tocassem com eles.

Esse episódio reforça o caráter de encontro da Roda. Sendo um encontro, os músicos se importam menos com a audiência do que com os próprios músicos. Em entrevista, um dos músicos frequentadores dessas Rodas afirmou: $n a$ roda, eu toco para os músicos, e, no palco, para o público. Outro objetivo da Roda de Choro é o aprendizado do gênero, o conhecimento do repertório e a tomada de familiaridade com sua linguagem. A Roda é considerada a escola por excelência do bom chorão, conforme indica 0 relato do violonista de sete cordas LP (Ex.2): 
LP: Geralmente quando a gente fala de choro, a gente fala de regional de choro, então fala de grupo, fala de pessoas. Ele pode ser um solista, tocar os temas, tocar sozinho, mas o esquema da roda de choro é único. É diferente tocar sozinho e tocar em grupo, acompanhado pelo pandeiro, pelo 7 cordas. É uma outra pressão, um outro entendimento.

Ex.2: Relato de violonista acerca da importância da Roda de Choro.

Mesmo reconhecendo o papel do aprendizado formal, HN, violonista de 7 cordas, atribui à Roda importância fundamental na formação do músico (Ex.3):

HN: Meu aprendizado musical eu devo muito mais às rodas do que ao ensino formal e universitário. 0 conhecimento acadêmico te orienta, mas pra você ser músico mesmo, aí tem que tocar. Não deve ficar restrito à noite, tocar em boteco, isso não, porque aí o cara joga fora a vida dele toda. No boteco ninguém está ouvindo você tocar. Tem que se gabaritar para ser um grande músico, sacou? Fazer grandes trabalhos, isso é indispensável. A roda de choro, o boteco, ninguém está te ouvindo tocar, mas mesmo assim você tem que tocar neles, acompanhar cantores e tudo o mais. Essa é a maior escola, sem desmerecer a Universidade, claro, porque as coisas se complementam. A Universidade te dá só um polimento.

Ex.3: Relato de violonista acerca da importância da Roda de Choro para o aprendizado do gênero.

Observamos, pelo relato acima, que o chorão em questão tem conhecimento de diversos contextos em que o Choro acontece. Para ele, tocar na Roda de Choro é indispensável para o aprendizado do gênero, mas é igualmente importante tocar em apresentações, gravações e em outros contextos, bem como tocar outros gêneros além do Choro. Isso reforça a ideia de que a polaridade Roda de Choro/apresentação é algo sempre presente na realidade desses músicos, pois faz parte de sua formação a performance em ambos os contextos.

Na Roda, há uma regra clara: quem quiser tocar, pode tocar, desde que seja na roda e que tenha capacidade para tal. Certa vez, na Tartaruga Lanches, um desconhecido solicitou uma participação; como sua performance não foi condizente com o nível musical da Roda, foi sutilmente expulso, com frases incentivadoras, do tipo: "ô amigo, tente estudar mais um pouco".

Diz-se que a Roda é aberta, ou seja, em princípio, nela é permitida a participação de qualquer músico. A depender do nível técnico e de conhecimento do Choro daqueles que a compõem, existe um grau de cobrança de desempenho que pode excluir um grande número de músicos. $A$ Roda da Tartaruga tem marcadamente essa característica. Muitos instrumentistas iniciantes relatam que não têm coragem de tocar, acreditando não possuir nivel suficiente para participar. Essa impressão é causada, em parte, porque um bom número dos músicos participantes dela é considerado como os "bons" de Brasília. Também contribui para isso o hábito que os músicos têm de cobrar boas atuações. Não são poupados comentários e brincadeiras; se um participante está a comprometer por demais a execução da música, é solicitado que algum outro músico assuma seu instrumento. Até mesmo músicos frequentes da Roda são alvo de críticas que chegam a ser severas a ponto de criar desentendimentos pessoais (Ex.4).

0 cavaquinista, enquanto solava um baião rápido, olhava para o pandeirista e tentava corrigir um erro que ele estava cometendo naquele pedaço da música. Tanto o cavaquinista quanto o pandeirista são músicos habituais da Tartaruga Lanches. Depois, chamou novamente a atenção do pandeirista, dizendo "está caindo, está caindo", referindo-se ao fato de o pandeirista estar atrasando um pouco o andamento da música. Após um breque, o pandeirista teve dificuldades em voltar a tocar no tempo certo. 0 cavaquinista, então, fazia caras e bocas, dizia "não, não!", e expressava impaciência e descontentamento; demais participantes da Roda estavam levemente apreensivos. Alguns riam dos erros do colega, outros aguardavam o desfecho da situação. Quando a música terminou, iniciou-se o seguinte diálogo:

Cavaquinista (dirigindo-se ao pandeirista): mas foi ruim demais, hein? Caiu muito [ou seja, o andamento ficou mais lento], caiu demais. Assim não dá.

Pandeirista: mas também a música é rápida demais.

Cavaquinista: Pois é. Vou te dar um conselho. Volta para a Escola de Choro [Raphael Rabello]. Volta para lá, você consegue até uma bolsa. Volta para lá para aprender a tocar.

Pandeirista (levantando-se e deixando o pandeiro sobre a mesa): Alguém vem tocar no meu lugar aqui, porque não tenho capacidade para tocar nessa Roda.

Nisso, alguns integrantes da Roda tentaram minimizar o malestar, com frases do tipo: o que é isso, também não é assim, calma, não liga não.

Em vão, pois o pandeirista, visivelmente magoado, abandonou a Roda.

Ex.4: Descrição de episódio ilustrando o modo como os músicos cobram boas performances no contexto da Roda de Choro.

De fato, o que se observa na Roda é que, embora sempre se afirme que ela é aberta, tal abertura não é absolutamente irrestrita. As limitações se impõem, principalmente, em função de performances não satisfatórias. 0 caso descrito acima mostra a exclusão de um músico considerado de casa - cuja aceitação comumente não é posta em questão - em função de sua performance ter sido considerada ruim naquele momento.

Em geral, a Roda fica sob o comando de um músico, definido tacitamente entre todos; o critério para tal pode ser experiência, nível técnico ou de conhecimento musical. Se o "comandante" deixa seu posto, automaticamente 0 comando se transfere para outro. No Tartaruga, há a presença constante de um cavaquinista cujo virtuosismo é notável, embora seja muito jovem. Em geral, a Roda fica 
sob seu comando. Algumas vezes, músicos mais velhos e experientes aparecem para participar; nesses momentos, é evidente a reverência com que são tratados por todos, e o comando da Roda Ihes é gentilmente cedido.

Todavia, há casos em que instrumentistas virtuosos aparecem para tocar, músicos que vêm se apresentar no Clube do Choro ou músicos que não frequentam assiduamente a Roda da Tartaruga. Nesses momentos, o comando da Roda fica em xeque (Ex.5). Observa-se, então, que se iniciam duelos entre solistas e, do mesmo modo, os acompanhadores são postos à prova. Quando isso acontece, os músicos menos experientes ficam de fora, e são chamados para compor a Roda somente aqueles considerados os melhores. Em entrevista, o cavaquinista MM afirmou:

MM: [para tocar choro] tem que estar naquele convivio da Roda. Tem que ter aquele esquema do desafio. Eu acho que Roda de Choro é isso, o desafio, testar o cara para ver se ele vai dar conta. Se ele se ferrar, a galera vai ficar feliz, porque você conseguiu derrubar o cara. Roda de Choro tem muito isso

Ex.5: Relato acerca da existência de duelos entre instrumentistas na Roda de Choro.

Outro cavaquinista fez observações semelhantes (Ex.6):

LB: Roda é isso, chega o solista e diz: vou tocar tal choro, você tem que se virar pra acompanhar (...). 0 tom é tal, vamos atrás. Poyares fazia isso com a gente direto, às vezes inventava uma música e a gente tinha que acompanhar, tinha que correr atrás. Às vezes, o cavaquinista dá uma palhetada invertida, tira a acentuação do tempo, para ver se o solista também não se perde. Igual quando a gente vai tocar com o Evandro, ele enrola a galera. Pode estar tocando o choro mais simples do mundo, o Carinhoso, que ele desloca a melodia, atrasa, adianta. Se o cara não estiver atento, cai na hora. É coisa da roda.

Ex.6: Relato que demonstra a forma como os músicos testam uns aos outros na Roda de Choro.

0 duelo musical entre instrumentistas é, então, um dos elementos importantes da Roda de Choro. Consiste basicamente na comparação entre as performances, em que são julgados: técnica, conhecimento e criatividade para interpretar e improvisar. A responsabilidade daquele que não quer perder o comando da Roda é grande, pois ele não pode errar; por outro lado, tem a vantagem de "estar em casa", ou seja, conhecer os acompanhadores e o ambiente. 0 forasteiro, por sua vez, pode testar o regional como um todo: por exemplo, é considerado humilhante se ocorrer de ele propor uma música que os acompanhadores não conheçam e não sejam capazes de executar. Por outro lado, ele perderá a oportunidade de permanecer tocando se cometer um deslize muito grave, como esquecer a música que ele mesmo propôs ou cometer um erro rudimentar (principalmente se perder o ritmo). Nesse pon- to, o regional pode testá-lo também, fazendo variações rítmicas inesperadas - no caso do pandeiro e do cavaco -, ou frases contrapontísticas do violão que tirem a concentração do solista, ou mesmo acelerando o andamento da música (embora nem sempre isso seja considerado leal). 0 solista "de casa" tem a incumbência também de "manter seu reinado". Por exemplo, quando um deles propõe uma música conhecida por ambos, o duelo então se acirra, por meio de improvisos e aumento dos andamentos, até que fique claro qual deles se saiu melhor, ou até que a música termine (Ex.7). Nem sempre sai um vencedor do duelo, mas é certo que todos ganham nessas ocasiões, principalmente a audiência de músicos e frequentadores:

DD: Se eles [os músicos de casa] sacarem que o cara é carne nova no pedaço e vai dar uma canja, dependendo do cara, eles botam quente. Se eles sacarem que o cara toca bem e está tocando tudo o que eles estão fazendo, uma hora eles vão jogar uma música para ferrar o cara. Ou às vezes eles podem se ferrar. Eles acham que o cara não sabe, mas o cara sabe. Como já aconteceu no Rio com E. Foram tocar uma música, acharam que determinada pessoa não sabia a música, mas se ferraram, porque o cara sabia e tocou a música. Depois E. jogou contra, e puxou uma música que eles não souberam. Se ferraram. [Em outra ocasião], E. foi para São Paulo, e os paulistas tocavam altas músicas para sacanear, músicas que ninguém conhecia, e ele tocou todas. Então, ele puxou uma música, aquela 'pra esquecer', do Waldir, aí os caras não foram. E. deixou o cavaquinho na mesa, saiu da roda e falou: vocês não tocam nada. Então, você pode se surpreender, querer dar uma de bonzão e se dar mal.

Ex.7: Relato de violonista narrando um episódio em que um músico convidado foi testado pelos demais em uma Roda de Choro.

Outro instrumentista também observou e comentou sobre as mesmas situações (Ex.8):

HN: Assim, a roda de choro sempre tem o espírito de testar o outro. No Rio [de Janeiro], acho que se acentua mais esse espirito, porque tem muita concorrência lá. Também tem esse lance, que está estampado na cara do carioca, de que ele é malandro. Então ele chega já botando uma música que ele sabe que você não vai tocar, de uma maneira até meio perversa. Aqui em Brasília também tem isso, lógico. Mas tem um lance do desafio saudável. Lá eles derrubam para ver teu oco, mas isso é o espírito do choro. Acho que ele foi formado assim, isso não é uma coisa ruim. Acho que quando isso acontece, de você não saber tocar, isso te motiva a estudar mais, a conhecer mais repertório. Tem que estar preparado para isso.

Ex.8: Relato de violonista confirmando e reafirmando a importância dos duelos e testes na Roda de Choro.

Embora seja inegável sua importância, nem sempre o duelo está presente. Muitas Rodas acontecem em clima constante de amizade, compadrio e companheirismo, sem por isso, serem consideradas piores. Outros fatores são considerados importantes no contexto da Roda (Ex.9). 
DD: Eu acho [importante para a Roda] a descontração, encontrar os amigos e aprender com o outro. Tem gente que não traz coisas novas, tem um repertório de 15 músicas, mas tem muita gente que traz coisas novas, tem muita canja e isso é legal. Tomar umas, descontrair.

Ex.9: Relato de violonista enfatizando o caráter doméstico da Roda de Choro.

Do mesmo modo como ocorrem nas rodas de samba (MOURA, 2004), as relações pessoais, de afeto e de amizade, importantes para a vida dos músicos mesmo fora do âmbito estritamente pessoal, tem relação com a Roda de Choro, pois ela é local de formação de vínculos (Ex.10), conforme evidenciado no relato de AS:

AS: Se você toca numa roda de choro, já está fazendo amizade automaticamente. Claro que essa amizade, às vezes, se restringe mais ao campo profissional, mas não deixa de ser uma amizade. Também tem muitos músicos antigos aqui em Brasilia, e a gente já toca há muito tempo. Então, a gente tem uma relação de amizade.

Ex.10: Relato sobre a Roda de Choro como local propício para formação de laços de amizade.

A existência, no mesmo ambiente da roda, de dois modos de relacionamento entre pessoas - desafio/competição e compadrio/amizade/afeto/lealdade - aparentemente contraditórios, revela um outro aspecto interessante da Roda de Choro: seu caráter lúdico. A música como jogo ou brincadeira amplia a sensação de informalidade e festa (Ex.11). 0 seguinte relato menciona o desafio como brincadeira na roda de choro:

LB: Não tem, na história do samba, grandes cantores. 0 que importa não é a voz, é a interpretação, deslocando o tempo, atrasando, adiantando. Isso pra mim é improvisar (...). Toda a roda, na cultura brasileira, tem esse negócio do desafio, do duelo. Na capoeira os caras são amigos, mas tão duelando; na roda de partido alto, também. Era tudo improviso, só tinha o refrão. Na roda de choro também tem esse lado; por ser roda, tem desafio.

Ex.11: Relato de cavaquinista afirmando o caráter de jogo e brincadeira da Roda de Choro.

PELLEGRINI (2005) também faz referência à brincadeira nessa modalidade musical:

Pode-se testemunhar esse clima de brincadeira ainda hoje em qualquer roda de choro em que, mesmo se tocando melodias conhecidas, vê-se o solista alterando as melodias de tal maneira que um acompanhamento pouco treinado, muitas vezes, acaba por se perder. (PELLEGRINI, 2005, p.25)

Imprimir a qualidade de jogo à música, contudo, não reduz o respeito com que os músicos e audiência consideramna. Para tocar na Roda, é necessário conhecer seus códigos e ter capacidade de tocar bem o instrumento; ou seja, é preciso levar a sério a música e o ambiente da Roda.
0 termo brincadeira, na Roda de Choro, não é antagônico à seriedade. A música como brincadeira de roda pode, porém, indicar uma resistência à institucionalização da Roda, que a converteria em espetáculo. Se ocorrer essa conversão, obrigatoriamente a Roda perderá algumas de suas características informais, dentre elas, a brincadeira e o jogo. No espetáculo, não há lugar para a imprevisibilidade do jogo, tampouco para a vulnerabilidade do jogador que pode cair ou perder a qualquer momento; nele, tudo deve ser ensaiado previamente. Então, o ambiente de festa e encontro cederia lugar ao formal e profissional; nesse ponto, o evento não mais poderia ser considerado uma Roda. Esse é, sem duvida, o risco de as Rodas de Choro que assimilam elementos de apresentações formais (como amplificação de som e pagamento de cachê) sempre correrem. Caso as características da apresentação passem a ter primazia sobre aquelas da Roda, ela pode, aos poucos, ir deixando de funcionar como tal, porque a Roda é resistente à institucionalização desde a sua essência.

Embora marcada pela informalidade e pela brincadeira, há aspectos da Roda tratados com verdadeira austeridade. Um deles é o repertório. Ele deve ser composto majoritariamente por Choros, embora possam ser incluídos, com muito critério, sambas, baiões e outros ritmos. 0 repertório das Rodas da Tartaruga varia, evidentemente, com os músicos solistas presentes. Não há nenhuma determinação prévia do que será tocado, mas algumas músicas fazem parte do cânone, e são tocadas em praticamente todas as Rodas. Autores como Jacob do Bandolim, Pixinguinha, Waldir Azevedo estão sempre presentes; e são tocados vários instrumentos. Uma regra rígida, em Brasília, consiste em não repetir a mesma música na mesma Roda. Portanto, se um solista chega depois do início da Roda, pergunta aos demais se determinado choro já foi tocado. Outra regra firme é a proibição do uso de partituras ou outros registros escritos. É extremamente valorizada, por parte dos músicos, a ampliação dos repertórios dos solistas, inclusive com o acréscimo de composições contemporâneas. Também se apreciam as inovações interpretativas trazidas pelos solistas. A Roda cobra dos músicos a variação nas interpretações, e critica, com sorrisos sarcásticos e olhares de lado, as reproduções sempre iguais. Desse modo, a Roda torna-se um fator de preservação, divulgação e renovação da tradição do Choro.

Normalmente, a Roda se inicia por volta das 18h30, com choros lentos e cadenciados, quando a audiência é ainda pequena. A partir das 19h30, com público maior, são tocados choros mais rápidos, e parte da audiência já se aglomera ao redor da mesa dos músicos, dançando ou simplesmente observando as performances de choros rápidos e alguns lentos, com clara preferência dos músicos pelos mais rápidos. É comum aos solistas a realização de sequências de sambas, bossa-nova ou baiões, que são do agrado do público. A partir das 20h00, o clima de informalidade aumenta, as pessoas falam mais alto e reagem aos acontecimentos musicais da Roda. Um improviso impressionante é reconhecido por gritos e palmas tanto dos demais mú- 
sicos quanto da audiência. Quanto maior for o número de pessoas, quanto mais sua atenção estiver voltada para a música, quanto mais elas gritarem, maior será o incentivo para os músicos, e a Roda se torna mais vigorosa e cresce em volume de som e no andamento das músicas. Para a última música da Roda, os músicos guardam os choros "apoteóticos"; dentre os mais comuns tocados estão Brasileirinho (Waldir Azevedo), Santa Morena (Jacob do Bandolim) e Aquarela na Quixaba (Hamilton de Holanda).

Em todas as músicas do repertório, o improviso pode acontecer; é comum, contudo, que muitas músicas sejam tocadas sem improvisos, às vezes com pequenas variações na linha melódica, ou sem variações. Existem algumas consideradas mais "propícias" ao improviso: por exemplo, podemos citar Cochichando, de Pixinguinha, e Noites Cariocas, de Jacob do Bandolim, como Choros em que o improviso é sempre presente. Quando são tocadas, normalmente as partes são repetidas muitas vezes (alterando a forma da música) para que todos os músicos participantes improvisem. Praticamente todos os músicos entrevistados afirmaram considerar o improviso imprescindivel no Choro e na Roda. No improviso, o músico se despe das preparações prévias à performance, e mostra o seu real domínio e conhecimento da linguagem do Choro. Além disso, traz a possibilidade de se expressar individual e pessoalmente. Por isso, na Roda de Choro, contexto em que vigora o primado da pessoalidade, 0 improviso é considerado fundamental.

Há, porém, falta de consenso entre os chorões acerca da quantidade de solos improvisados que uma performance pode conter, bem como acerca do modo como são realizados. Há aqueles críticos dos músicos que exageram nos improvisos; normalmente, é cobrada a apresentação do tema. Todavia, alguns músicos consideram desnecessária a apresentação do tema em uma Roda de Choro (principalmente nas músicas muito conhecidas), e não se incomodam de executar uma música inteira somente improvisando. Essas divergências resultam, ocasionalmente, em discussões na Roda, por vezes no meio da música, como ilustra o episódio abaixo:

A música era Cochichando, havia três solistas (cavaquinho, flauta e gaita), mais o violão de 7 cordas, o violão de 6 , o cavaquinho-centro e o pandeiro. 0 cavaquinho puxou a primeira parte incluindo variações e improvisos; a flauta a repetiu sem improvisar. $\mathrm{Na}$ segunda parte, 0 mesmo se sucedeu. A partir daí, o cavaquinista e o gaitista intercalavam improvisos, pedindo as partes da música aleatoreamente, sem respeitar a forma. A terceira parte já havia sido repetida várias vezes (inclusive com improvisos dos violões), sem que o tema fosse apresentado. 0 cavaquinista-centro pediu, então, que algum dos solistas apresentasse o tema. Quando a música terminou, alguns músicos não esconderam a insatisfação, reclamando muito do excesso de improvisos e do desrespeito à forma do choro. Seguiu-se uma pequena discussão, até a próxima música fosse iniciada, e o entrevero esquecido.
Os seguintes relatos expressam a opinião de músicos que defendem maior parcimônia nos improvisos (Ex.12):

LB: 0 respeito na roda é todo mundo saber o que fazer e quando fazer. Chego lá na roda da Tartaruga, e está todo mundo estudando improviso. Tocou a música, ai repete a segunda ou a terceira parte vinte vezes. Só o cara que está improvisando é que está gostando. Quem é músico está entendendo tudo. Mas imagina quem não é? 0 público não entende nada. Fica aquela coisa massante, igual ao Jazz. 0 tema dura 30 segundos, mas a música dura duas horas. Tudo tem um limite.

DD: Até nas repetições das músicas, a galera esqueceu da forma das músicas (...). Faz três vezes a primeira, a segunda faz uma vez, aí já muda pra terceira, faz três vezes a terceira. Aí confunde tudo, porque perde a forma.

LB: Isso é primordial. A forma é primordial. Porque se é uma música de improviso, você não sabe onde ela vai acabar e o que vai acontecer. Então, pelo menos a forma tem que estar definida.

DD: Isso está acontecendo em Brasilia, não é só na Tartaruga, a gente tem a referência da Tartaruga, porque a maioria dos músicos de Choro está se encontrando lá, e ela se tornou a maior Roda de Choro aqui de Brasilia. Os solistas, e até mesmo os violonistas, ficam toda hora pedindo para improvisar, toda hora falam tal parte para mim, para mim. Aí então acaba afetando a forma, porque é um tal de pedir para mim, para mim, que a gente não sabe se faz uma vez a [parte] $A$, outra vez a $B$. Porque as vezes você está na $A$, então alguém fala: três, três [solicitando a parte $C$, às vezes chamada de terceira ou parte três], eu pulo do $A$ para o $C$, sem fazer a forma da música toda. Ai fica sem sentido a coisa, e a música mesmo, que era pra ser apresentada, não acontece.

LB: Tem que apresentar o tema, e improvisar depois.

Ex.12: Relatos sobre improviso no Choro.

É fato que, embora o improviso seja sempre aceito e considerado indispensável, há pontos de conflito relacionados a ele. Os músicos mais conservadores entendem que o tema de uma música não pode desaparecer por longos períodos em sua execução, como acontece no Jazz; também há polêmicas quanto à perda da linguagem do Choro, uma vez que muitos músicos, por sua formação eclética, utilizam técnicas do Jazz para improvisar. Por outro lado, outros defendem o acontecimento de improvisos, principalmente nas Rodas de Choro, longos e que tomam boa parte da execução da música. Em virtude dessas divergências, o que se observa nas rodas é uma grande diversidade de modos de executar os choros, com ou sem improvisos; esses últimos podendo ser longos ou curtos, ser próximos ou distantes da melodia da música.

Com efeito, controvérsias em relação ao improviso no Choro não são recentes. CAZES (2005) afirma que a improvisação, do surgimento do Choro até as primeiras décadas do século $X X$, era inexistente nas gravações, o que levou Hermano Vianna, no prefácio do livro Choro: do quintal 
ao municipal (CAZES, 2005, p.8) a concluir que isso torna muito provável a afirmação de que não se improvisava na roda de choro. KORMAN (2004), por outro lado, afirma que o improviso esteve presente no Choro desde suas origens, ainda no século XIX. Segundo esse autor, no início do século $X X$, o Choro incorporou influências do jazz norte-americano, do ragtime, dos fox-trots. Nas décadas de quarenta e cinquenta, foi influenciado pelo bebop, cool jazz, swing, ballroom e hard bop.Em todos os casos, o uso de técnicas e de linguagens oriundas desses gêneros estrangeiros gerava polêmicas e discussões entre os músicos brasileiros. $A$ escassez de registros torna difícil saber se havia ou não improvisos no Choro, bem como conhecer com precisão como eram feitos. Mas o próprio CAZES (2005) afirma que as gravações do início do século XX da flauta de Pixinguinha apresentam o brilho especialíssimo de suas interpretações e de seus improvisos. É possivel que improvisos estivessem ausentes das gravações, por questões de ordem técnica e financeira, mas isso não significa que, em outros contextos, notadamente com alto grau de informalidade como as Rodas de Choro, eles não ocorressem.

KORMAN (2004) afirma que na nova fase que o Choro vive, seus praticantes tem familiaridade com a linguagem do jazz americano, e isso vem alterando o vocabulário de improvisação do Choro. 0 autor identifica algumas mudanças no modo de tocar o Choro, dentre as quais as seguintes estão presentes nas Rodas da Tartaruga Lanches: a forma da música é alterada, possibilitando a improvisação sobre uma sequência harmônica cíclica; aspectos da performance jazzistica estão sendo apropriados e usados livremente; repertório, fragmentos melódicos e fraseados da tradição brasileira têm sido incluídos no vocabulário comum do Choro; praticantes estrangeiros estão cada vez mais familiarizados com o gênero. Observamos, contudo, que a inserção dessas mudanças não se dá de forma harmoniosa, pois gera desavenças entre seus praticantes. Os relatos dos músicos também permitem concluir que, em geral, têm plena consciência desse processo de mudança pelo qual o Choro está passando, e não se furtam a tomar posição perante elas, seja concordando ou discordando. A existência dessas controvérsias, bem como a possibilidade de introduzir inovações no modo de tocar o Choro, indicam que a Roda de Choro da Tartaruga é um contexto em que é possivel a renovação da tradição do Choro.

De fato, Roberto MOURA (2004), quando afirma que a roda é a matriz do samba, está a dizer que é precisamente nesse contexto em que se processa o desenvolvimento do gênero; ou seja, é na Roda que as inovações são testadas, podendo ser aceitas e incorporadas ou não ao gênero. 0 mesmo é válido para o Choro. As Rodas da Tartaruga são locais em que esses testes podem acontecer, e as polêmicas e controvérsias acerca das inovações ao gênero podem ser discutidas e amadurecidas. As seguintes características da Roda de Samba apresentadas por MOURA (2004) também estão presentes na Tartaruga Lanches: compadrio, amizade, lealdade, hierarquia e informalida- de. Também é nítido o caráter doméstico e familiar da relação entre músicos e boa parte da audiência. 0 fato de os músicos tocarem para os músicos e da Roda cobrar que toquem juntos, sem predeterminações de arranjos ou interpretações, reforça o caráter de construção coletiva da música. A tradição se renova, então, pela constante reformulação interpretativa das composições.

É preciso enfatizar, contudo, que a Roda da Tartaruga Lanches incorpora alguns elementos típicos de apresentações, sendo os mais importantes a contratação de um grupo fixo de instrumentistas, mediante pagamento de cachê, amplificação de som e presença de pessoas externas ao círculo de amizades e relações dos músicos. Além disso, em determinadas situações, alguns instrumentistas não têm acesso a participar da Roda, principalmente em função do nivel de habilidade. Esses elementos, porém, não fazem com que os músicos, nem a audiência, deixem de considerar o evento como uma autêntica Roda de Choro.

Também são presentes nessa Roda formas de duelo musical, ocorridos quando um instrumentista desafia outros, transformando a música em uma espécie de jogo. Esse modo de executar a música remete a outras manifestações de roda típicas da cultura afrobrasileira, baseadas em duelos e desafios. Já citados nesse trabalho como tais são a capoeira, com duelos corpóreos e improvisados, e o partido-alto, que consiste em duelos musico-verbais também improvisados. É interessante ressaltar que os termos empregados pelos chorões, ao se referirem aos duelos, se assemelham àqueles do universo da capoeira (cair, derrubar, levantar etc); em um dos relatos, inclusive, um cavaquinista chegou a comparar o duelo da Roda de Choro com o jogo da capoeira.

\section{4- Conclusão}

Os relatos dos chorões apontam para a importância da existência de Rodas para manutenção e recriação da tradição musical do Choro. Podemos, então, afirmar que, do mesmo modo como ocorre com o Samba (MOURA, 2004), a Roda é a matriz do Choro. E as características da Roda nos mostram que, para esse gênero musical, uma série de fatores extra-musicais interferem de modo significativo nas performances dos músicos, no desenvolvimento e na criação da música. Esse modo de conceber a arte é coerente com a perspectiva de Gerard Béhague, que afirma que o sentido da música não pode ser compreendido a partir de uma única fonte (BÉHAGUE, 1984, p.8). As implicações dessa afirmação são inúmeras, e seria impossível explorá-las todas aqui. Conseguir apreender o sentido do Choro como gênero musical talvez seja o maior desafio da musicologia que pretende estudá-lo, e esse trabalho mostra que a Roda de Choro tem muito a nos revelar sobre isso. Nessa modalidade os elementos não musicais encontram-se, de alguma maneira, dentro da música, como partes importantes em sua execução, interpretação e criação. A Roda de Choro é um local em que a música é tão importante quanto a existência pessoal de músicos 
e ouvintes, porque não se separa dos demais aspectos da vida, e funciona como ponte comunicativa, que permite 0 encontro e a relação entre pessoas.

A imbricação entre música e contexto é tão marcante no Choro que não é possível falar de Choro sem se referir ao seu contexto. Essa inseparabilidade não é exclusiva do Cho- ro, como nos ensinam musicólogos como Jonh Blacking e Gérard Béhague. Ela faz parte da música. Não existe sistema musical em que a música esteja separada dos aspectos não-musicais. A música é coisa dos homens, das coletividades humanas organizadas por suas culturas. A ordem sonora é reflexo da ordem vigente na sociedade. Então, a música está enraizada na realidade, e é daí que emana seu sentido.

\section{Referências}

BÉHAGUE, Gerard. Performance Practice: Ethnomusicological Perspectives. Westport/London: Greenwood Press, 1984. BLACKING, John. Music, Culture and Experience. Chicago: The University of Chicago Press, 1995.

CASCUDO, Câmara. Dicionário do Folclore Brasileiro. 11ª edição, São Paulo: Global Editora, 2002. 768 pp.

CAZES, Henrique. Choro: do quintal ao municipal. 3a Edição, Rio de Janeiro: Ed. 34, 2005, 224 pp.

DAMATTA, Roberto. A casa e a rua. Rio de Janeiro: Ed. Rocco, 1997.

KERMAN, Joseph. 0 movimento da performance histórica. In: Musicologia. São Paulo: Martins Fontes, 1987. p.255-306.

KORMAN, Clifford. A Importância da Improvisação na História do Choro. In: Anais do V Congresso Latino Americano da Associação Internacional para o Estudo da Música Popular, Rio de Janeiro, 2004. [disponível em http://www.hist. puc.cl/iaspm/rio/Anais2004\%20(PDF)/CliffKorman.pdf].

LIVINGSTON-ISENHOUR, Tamara E.; GARCIA, Thomas G. C. Choro. A Social History of a Brazilian Popular Music. Indianapolis: Indiana University Press, 2005, 254 pp.

MOURA, Roberto M. No princípio, era a Roda: um estudo sobre samba, partido alto e outros pagodes. Rio de Janeiro: Rocco, 2004. 318 pp.

PELLEGRINI, Remo T. Análise dos Acompanhamentos de Dino 7 Cordas em Samba e Choro. Dissertação de Mestrado, Universidade Estadual de Campinas - UNICAMP, 2005, 250 pp.

PINTO, Alexandre G. Choro: Reminiscências dos Chorões Antigos. Rio de Janeiro: Funarte, 1978.

QURESHI, Regula B.. Musical Sound e Contextual Input: A Perfomance Model for Musical Analysis. Ethnomusicology, $31: 1,56-86,1987$

REIS, Letícia V.S. 0 mundo de pernas para o ar: a capoeira no Brasil. São Paulo: Publisher, 1997.

SCHUTZ, Alfred. Making Music Together - A Study in Social Relationship.In: Dolgin, J.L. Kemnitzer, D.S \& Schneider, D.M. (eds), Symbolic Anthropology - A Reader in the Study of Symbols and Meanings. New York: Columbia University Press, 106-119, 1977.

VIANNA, H. O Mistério do Samba. Rio de Janeiro: Jorge Zahar Editora, 1995. 193 pp.

VIEIRA, Luiz Renato e ASSUNÇÃO, Matthias Rohrig. Mitos, Controvérsias e Fatos: Construindo a História da Capoeira. In: Revista de Estudos Afro-Asiáticos n 34. Rio de Janeiro: Universidade Cândido Mendes, 1998.

WEBER, Max. A Objetividade do conhecimento na Ciência Social e na Ciência Política. In: Metodologia das Ciências Sociais. 2a ed., São Paulo: Editora Cortez, 1993.

Ivaldo Gadelha de Lara Filho iniciou seus estudos na Escola de Música de Brasilia, obteve o bacharelado em clarineta na classe do professor Ricardo Dourado Freire na Universidade de Brasilia. Em 2009, concluiu seu mestrado na área de Musicologia no programa de Pós-Graduação Música em Contexto da Universidade de Brasília. Atualmente é técnico de música do SESC-DF.

Gabriela Tunes da Silva iniciou a realização de trabalhos acadêmicos na área de biologia, na Universidade de Brasília. Seguiu nas ciências biológicas até terminar o Mestrado em Ecologia, pela mesma universidade, em 1999. Ingressou no Doutorado em Desenvolvimento Sustentável, ainda na Universidade de Brasília, em 2001, quando teve contato com as ciências humanas e sociais. Iniciou, então, a prática amadora de flauta transversal, aprendendo em aulas particulares, em rodas de choro e na convivência com a comunidade de músicos chorões de Brasília. Após o término do Doutorado, aprofundou leituras e estudos sobre história do choro e antropologia da performance musical. Atualmente, é servidora concursada da Câmara Legislativa do Distrito Federal, onde desempenha a função de consultora legislativa.

Ricardo Dourado Freire cursou o Bacharelado em Clarineta na Universidade de Brasilía com o professor Luiz Gonzaga Carneiro. Continuou seus estudos na Michigan State University recebendo os diplomas de Mestrado em Música (MM), em 1994, e Doutorado em Artes Musicais (DMA), em 2000, sob a orientação da Dra. Elsa Ludewig-Verdehr. Sua tese intitulada a "Historia e Desenvolvimento da Clarineta no Brasil" serve como principal referência para os interessados na trajetória dos clarinetistas brasileiros. Realiza pesquisas nas áreas de Performance, Educação Musical, Psicologia Cognitiva vinculado ao aprendizado instrumental e Música Popular. 